\title{
Assessment of psychological indicators of domestic violence against children and youth from the child's behavior in the dental office
}

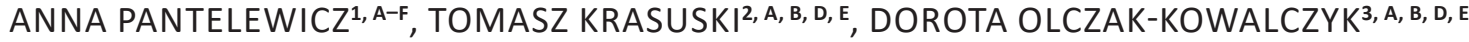 \\ ORCID ID: 0000-0003-1403-5442 \\ ORCID ID: 0000-0002-1567-3844 \\ ${ }^{1}$ Pediatric Dentistry Department, Warsaw Medical University, Warsaw, Poland \\ ${ }^{2}$ Medical Psychology Department, Warsaw Medical University, Warsaw, Poland \\ ${ }^{3}$ Head of Pediatric Dentistry Department, Warsaw Medical University, Warsaw, Poland
}

A - Study Design, B - Data Collection, C - Statistical Analysis, D - Data Interpretation, E - Manuscript Preparation, F - Literature Search, G - Funds Collection

Summary Background. Children experiencing domestic violence may demonstrate behavioral impairments and emotional instability during a stressful visit to the dentist.

Objectives. To identify the influence of domestic violence on a child's behavior in the dental office.

Material and methods. For the study, children under the protection of Family Support Centers (study group) and patients from normative families reporting for regular dental checkups (control group) were qualified. The consent of the WUM bioethics committee and the written consent of the parents/legal guardians of the patients, as well as participants above 16 years of age, were obtained. The examination consisted of a questionnaire, analysis of personal files, assessment of appearance and the child's behavior and reaction during dental treatment in relation to parents and the doctor.

Results. The study was carried out in 2017-2019 and involved 404 in the study group (average age 11.4 \pm 3.7 ) and 378 in the control group (average age $8.53 \pm 3.92$ ). The presence of physical $(n=123,30.45 \%)$, sexual $(n=19,4.7 \%)$ and emotional abuse $(n=266$, $66.34 \%$ ) in the study group was confirmed. Behaviors observed only in the study group were a sense of guilt, aggressive reaction to stress, self-mutilation, lack of basic hygiene and mismatched clothing. The study revealed a connection between physical and emotional abuse and behaviors coming from auto-aggressive reactions and reduced self-esteem. Sexual abuse was connected with excessive anxiety and aggressive and irritable reactions in the relationship with parents/caregivers and the doctor.

Conclusions. Children experiencing violence are characterized by typical behaviors, the knowledge of which can help to dispel doubts in case of suspicion of domestic violence.

Key words: psychology, dental officers, child.

Pantelewicz A, Krasuski T, Olczak-Kowalczyk D. Assessment of psychological indicators of domestic violence against children and youth from the child's behavior in the dental office. Fam Med Prim Care Rev 2021; 23(1): 41-48, doi: https://doi.org/10.5114/ fmpcr.2021.103156.

\section{Background}

Child maltreatment (abuse and neglect), by those close to them in particular, can lead to direct consequences, such as health and dental neglect and physical injuries, but also to serious disorders of a child's mental and social development. Research has shown that exposure to child abuse is associated with an increased risk of depression, anxiety, attempts at suicide, addiction and being a victim or perpetrator of violence in their adult life [1-3]. Child abuse is difficult to disclose, as it is concealed both by the perpetrators and the victims. The child is frequently afraid and, at the same time, almost always ashamed of looking for help. The victim feels guilty considers the violence as a norm but, in many cases, is not able to speak out and very often has problems in contacting the required person [4, 5]. Craniofacial, head, face and neck injuries occur in more than half of the cases of child abuse [6-8]. In these cases, we do not have problems with detection of child abuse [9]. In the article, we want to answer the question of how to recognize child abuse in the dental office and if this is possible to detect from the child's behavior. A child's behavior is an outward manifestation of inner stability and security. All types of abuse are damaging to children - physically, emotionally and psychologically - and can cause long-term difficulties with behavior and mental health development, including social development, cognitive development and physical health [5]. Children who experience abuse and neglects may fail to develop a secure attachment relationship with their parent or peers, which can lead to long-term social and psychological problems. There are identifiable features in the behavior of neglected and/or emotionally abused children. The American Academy of Child \& Adolescent Psychiatry (AACAP) has associated the behavior presented by children who are victims of abuse with the behavior characteristic of post-traumatic stress disorder (PTSD). The AACAP has recently proved that child abuse can manifest itself with unique clinical patterns, including specific signs and symptoms of varying degrees of intensity: losing interest in activities which normally gave them joy or pleasure, a regression to thumb-sucking, bed wetting or other age inappropriate behaviors, as well as loss of communication skills and severe concentration problems interfering with learning or social activities [10].

\section{Objectives}

The aim of this study is to identify the main psychological aspects of abuse (physical, emotional, sexual abuse and neglect) 
in childhood contributing to its identification and diagnosis in a dental practice.

\section{Materials and methods}

Children under 18 years of age were qualified to the study from Social Welfare Centers and Family Support Centers across the city of Warsaw. Children treated in the Pediatric Dentistry Department of Warsaw Medical University form the control group. Children who refused to participate in the research (oral examination and physical inspection), even with parental consent, were not included in the research. The main study was preceded by a preliminary study, as a result of which the group of children with suspected behaviors and reactions were separated, which later on formed the questionnaire used in the study. The questionnaire was prepared by a qualified psychologist. The research relied upon family reports from social welfare workers, medical and social interviews and observation of parent-child/ /doctor-child interactions, child behavior and observation of the spontaneous reactions to stressful situation of dental treatment. From family reports, information as follows was obtained: skipping classes, running away from home, acquaintances with peers, type of violence experienced, legal and socioeconomic status of the family, stay at an orphanage or ambulance service, being under probation, active „Blue Card” procedure substance misuse, stay at juvenile detention center. The research adapted methods from social cognition research to observe specific and spontaneous reactions and behaviors of children, investigating their capacity to face and deal with the stressful, and often new, situation of dental treatment. The study was conducted by one investigator. The child's behavior in the office was assessed on the basis of a questionnaire and concerns the child's attitude towards the doctor and parents/guardians and assessment of the child's mental condition, appearance, behavior and responses, e.g. withdrawal, anxiety, restless reaction to physical contact, disregard, excessive physical contact, reduced self-esteem, excessive self-confidence, sense of helplessness, indifference, guilt, excessive responsibility, reduced mood, hyperactivity, aggression or regression as a reaction to stress, abnormal body weight, inadequate clothing (weather, age, gender), neglect of basic hygiene. The behavior of the caregivers during the study was also observed - level of interest in the state of health, involvement in the treatment process. All the observations were consulted with a psychologist. These methods may be problematic, because they can be biased by misattributions and perceptual errors. The data was organized and grouped according to the study aims and analyzed using the STATISTICA 13.3 program. The Mann-Whitney U test, Spearman's rank correlation, chi-squared test and logit regression (OR, aOR) were performed. Statistical significance was established at a level of $p \leq 0.05$ value. The legal guardian of all children participating in the research signed a consent form. The project was approved by the Ethics Committee of Warsaw Medical University no. $K B / 14 / 2017$. All children participating in the study whose parents approved of a further treatment plan remain under the care of the Pediatric Dentistry Department.

\section{Results}

The study was carried out in 2017-2019 and involved 782 patients, including 404 children from dysfunctional families aged from 2 to 17 years old (average age $11.4 \pm 3.7$ ) and 378 from normative families (control group) (aged from 2 to 17 years old; average age $8.53 \pm 3.92)$. 83 parents/caregivers refused to sign the consent form to participate in the research. Lack of consent mostly concerned children in day care at the family support center and children from single-parent and foster families. The guardians did not give a reason for their refusal to participate in the study. 9 children, despite having signed the consent form, resigned from participation in the study and were also excluded from the study. Despite having the possibility of further dental treatment, only 178 (44.06\%) patients registered to remain in our clinic once the study ended. The characteristics of the examined groups, as well as socioeconomic data, are presented in Table 1.

\begin{tabular}{|c|c|c|c|c|}
\hline \multirow[t]{2}{*}{ Parameters } & \multicolumn{2}{|c|}{ Study group } & \multicolumn{2}{|c|}{ Control group } \\
\hline & $n$ & $\%$ & $n$ & $\%$ \\
\hline $\begin{array}{l}\text { Gender } \\
\text { boys } \\
\text { girls }\end{array}$ & $\begin{array}{l}173 \\
231\end{array}$ & $\begin{array}{l}42.8 \% \\
57 \%\end{array}$ & $\begin{array}{l}194 \\
184\end{array}$ & $\begin{array}{l}51.0 \% \\
48.7 \%\end{array}$ \\
\hline Social Welfare Center & 404 & $100 \%$ & 0 & $0.0 \%$ \\
\hline Superintendent & 141 & $34.9 \%$ & 0 & $0.0 \%$ \\
\hline Blue Card & 62 & $15.35 \%$ & 0 & $0.0 \%$ \\
\hline Large family & 91 & $22.52 \%$ & 21 & $5.6 \%$ \\
\hline Single-parent family & 225 & $55.69 \%$ & 3 & $0.8 \%$ \\
\hline Foster home & 138 & $34.16 \%$ & 0 & $0.0 \%$ \\
\hline Orphanage & 8 & $1.98 \%$ & 0 & $0.0 \%$ \\
\hline Emergency medical services & 36 & $8.91 \%$ & 0 & $0.0 \%$ \\
\hline Alcohol at home & 237 & $58.17 \%$ & 0 & $0.0 \%$ \\
\hline Drugs at home & 36 & $8.91 \%$ & 0 & $0.0 \%$ \\
\hline $\begin{array}{l}\text { Frequent visits to the police } \\
\text { station }\end{array}$ & 31 & $7.67 \%$ & 0 & $0.0 \%$ \\
\hline Sexual violence & 14 & $3.47 \%$ & 0 & $0.0 \%$ \\
\hline Physical violence & 89 & $22.03 \%$ & 0 & $0.0 \%$ \\
\hline $\begin{array}{l}\text { Mental violence (family } \\
\text { quarrels, being a witness to } \\
\text { domestic violence, etc.) }\end{array}$ & 266 & $65.84 \%$ & 0 & $0.0 \%$ \\
\hline Dysfunctional family & 404 & $100 \%$ & 0 & $0.0 \%$ \\
\hline $\begin{array}{l}\text { Age of parents } \\
20-29 \\
30-39 \\
>40\end{array}$ & $\begin{array}{l}92 \\
207 \\
105 \\
\end{array}$ & $\begin{array}{l}22.77 \% \\
51.24 \% \\
25.99 \% \\
\end{array}$ & \begin{tabular}{|l|}
44 \\
192 \\
142 \\
\end{tabular} & \begin{tabular}{|l|}
$11.64 \%$ \\
$50.79 \%$ \\
$37.57 \%$ \\
\end{tabular} \\
\hline $\begin{array}{l}\text { Education of parents } \\
\text { basic } \\
\text { secondary } \\
\text { higher }\end{array}$ & $\begin{array}{l}172 \\
194 \\
38 \\
\end{array}$ & \begin{tabular}{|l|}
$42.57 \%$ \\
$48.02 \%$ \\
$9.41 \%$ \\
\end{tabular} & \begin{tabular}{|l|}
18 \\
86 \\
274 \\
\end{tabular} & \begin{tabular}{|l|}
$4.76 \%$ \\
$22.75 \%$ \\
$72.49 \%$ \\
\end{tabular} \\
\hline $\begin{array}{l}\text { Family socioeconomic status } \\
\text { low } \\
\text { average } \\
\text { good } \\
\text { high }\end{array}$ & $\begin{array}{l}244 \\
144 \\
16 \\
0\end{array}$ & \begin{tabular}{|l|}
$60.4 \%$ \\
$35.64 \%$ \\
$3.96 \%$ \\
0
\end{tabular} & $\begin{array}{l}19 \\
102 \\
74 \\
90\end{array}$ & \begin{tabular}{|l|}
$5.03 \%$ \\
$26.98 \%$ \\
$19.58 \%$ \\
$23.81 \%$
\end{tabular} \\
\hline
\end{tabular}

Among patients from dysfunctional family, physical abuse was noted in 123 cases (30.45\%), 34 of which were identified during the study. During our study, we confirmed the previous diagnosis of the occurrence of sexual ( $n=14,3.47 \%$ ) and emotional abuse ( $n=266,65.84 \%)$ among children from the study group. The study identified 5 more cases of sexual abuse. Those identified during the study were referred to the appropriate authorities.

A comparative analysis of the studied groups showed significant differences in the frequency of occurrence of all evaluated parameters (Table 2).

Behavioral patterns that occured most frequently in the study group and, at the same time, did not occur in the control group were: sense of guilt ( $24 \%$ vs $0 \%$ ), self-mutilation ( $3.7 \%$ vs $0 \%$ ), lack of basic hygiene $(31.9 \%$ vs $0 \%)$, mismatched clothing - too big, too small, inadequate for the season or gender ( $25.7 \%$ vs $0 \%$ ).

An analysis of Spearman's rank correlation was performed in order to identify factors which can interfere with the obtained results. The results showed an inverse correlation between economic status and education level and the presence of dysfunction and abuse (Table 3). 


\begin{tabular}{|c|c|c|c|c|c|c|}
\hline \multirow[t]{2}{*}{ Group behavior } & \multirow{2}{*}{ Detailed description of the observed behaviors } & \multicolumn{2}{|c|}{ Study group } & \multicolumn{2}{|c|}{ Control group } & \multirow[t]{2}{*}{$p$} \\
\hline & & $n$ & $\%$ & $n$ & $\%$ & \\
\hline Anxiety & $\begin{array}{l}\text { confused attitude/looking away/staying silent/excessive anxiety (inade- } \\
\text { quate for the situation) e.g. resulting from physical contact/quiet loner }\end{array}$ & 156 & 39 & 6 & 2 & $<0.001^{*}$ \\
\hline $\begin{array}{l}\text { Auto-aggressive } \\
\text { behavior }\end{array}$ & $\begin{array}{l}\text { abnormal body weight/eating disorders/self-mutilation (in visible } \\
\text { places (e.g. hands)) }\end{array}$ & 183 & 45 & 120 & 32 & $<0.001^{*}$ \\
\hline $\begin{array}{l}\text { Reduced self- } \\
\text { esteem }\end{array}$ & $\begin{array}{l}\text { I cannot do anything }(4+) / I \text { am hopeless/weak/worthless }(11+) / I \text { am } \\
\text { worse than others }(11+) / I \text { am useless }(11+) / I \text { am stupid }(11+) / I \text { do not } \\
\text { like myself }(11+)\end{array}$ & 198 & 49 & 66 & 17 & $<0.001^{*}$ \\
\hline Over-confidence & $\begin{array}{l}\text { do not follow the recommendations, "I know better"/ignoring } \\
\text { a doctor/"anyway, I will do as I want"/ignoring the doctor and/or par- } \\
\text { ents, not answering the questions }\end{array}$ & 156 & 39 & 75 & 20 & $<0.001^{*}$ \\
\hline $\begin{array}{l}\text { Reduced mood and } \\
\text { motivation }\end{array}$ & $\begin{array}{l}\text { I will not be able to... [e.g. take care of my teeth, talk to my parents, } \\
\text { change my dietary and hygienic habits, etc.] }(7+) / / \text { won't be able to } \\
\text { change }(11+) / / \text { have no influence over anything }(11+) / \text { I don't care, it } \\
\text { doesn't make any sense }(+11) / \text { this had to be so [e.g. in the context of } \\
\text { the occurrence of cavities] }(11+) / \text { "So what?"/this will always be like } \\
\text { this [as above] }(11+) / \text { tearfulness "anemic behavior"/low vitality, apa- } \\
\text { thy/passive execution of commands/lack of motivation }\end{array}$ & 237 & 59 & 106 & 28 & $<0.001^{*}$ \\
\hline $\begin{array}{l}\text { Hyper-responsi- } \\
\text { bility }\end{array}$ & $\begin{array}{l}\text { positive reaction to delimitation/“meta-knowledge", a factual conversa- } \\
\text { tion like with an adult/taking responsibility for oneself, siblings/ } \\
\text { /psychical maturity inadequate for age/asking for recommendations on } \\
\text { their own, ignoring the presence of parents }\end{array}$ & 150 & 37 & 48 & 13 & $<0.001^{*}$ \\
\hline $\begin{array}{l}\text { Aggressive be- } \\
\text { havior }\end{array}$ & $\begin{array}{l}\text { escaping, violent jerking, pushing }(7+) / \text { attacking the doctor (kicking, } \\
\text { punching, pushing the doctor/caregiver away) }(7+) / \text { pejorative language } \\
(7+) / \text { anger discharge (hitting a wall/chair, destroying toys/medical } \\
\text { equipment) }(7+) / \text { aggressive reaction towards caregivers, anger/imper- } \\
\text { tinent answers to questions }\end{array}$ & 144 & 36 & 6 & 2 & $<0.001^{*}$ \\
\hline $\begin{array}{l}\text { Regressive be- } \\
\text { havior }\end{array}$ & $\begin{array}{l}\text { thumb sucking/excessive physical contact, shortening of distance, } \\
\text { possessive hugs/urinary incontinence/acting and speaking like a little } \\
\text { child/embarrassment inadequate to the situation }\end{array}$ & 131 & 32 & 53 & 14 & $<0.001^{*}$ \\
\hline Hyperactivity & $\begin{array}{l}\text { uncoordinated movements/interrupting the doctor during, conversa- } \\
\text { tion, giving recommendation or taking an interview/inability to stay } \\
\text { seated e.g. getting up from the chair, walking around the office, run- } \\
\text { ning away from the dental office opening drawers, touching medical } \\
\text { equipment/sudden activity changes/impulsive behavior/tantrum in } \\
\text { dental office e.g. rolling around on the floor screaming/do not respond } \\
\text { to questions/do not follow the instructions of doctor or guardian/ner- } \\
\text { vous play with hands }\end{array}$ & 164 & 41 & 73 & 19 & $<0.001^{*}$ \\
\hline Sense of guilt & $\begin{array}{l}\text { this is my fault, taking responsibility for parents/made mom and dad } \\
\text { feel sorry }(7+) / I^{\prime} m \text { making mom/dad/siblings cry }(7+) / \text { everything bad } \\
\text { that happens in my family is because of me }(11+) / \mathrm{mom} / \text { dad is angry } \\
\text { because of me }(11+)\end{array}$ & 96 & 24 & 0 & 0 & $<0.001^{*}$ \\
\hline \multicolumn{2}{|l|}{ Others: } & & & & & $<0.001^{*}$ \\
\hline \multicolumn{2}{|l|}{ Speech impairments } & 134 & 32 & 6 & 2 & $<0.001^{*}$ \\
\hline \multicolumn{2}{|l|}{ Onychophagia } & 105 & 26 & 0 & 0 & $<0.001^{*}$ \\
\hline \multicolumn{2}{|c|}{ Lack of basic hygiene, presence of lice } & 129 & 31.9 & 0 & 0 & $<0.001^{*}$ \\
\hline \multicolumn{2}{|c|}{ Mismatched clothing - too big, too small, inadequate for the season or gender } & 106 & 25.7 & 0 & 0 & $<0.001^{*}$ \\
\hline \multicolumn{2}{|c|}{ Signs of physical violence on hands, neck, face; cigarette marks on skin; self-mutilation } & 16 & 3.7 & 0 & 0 & $<0.001 *$ \\
\hline \multicolumn{2}{|c|}{ Child under the influence of psychoactive substances } & 22 & 5.4 & 0 & 0 & $<0.001^{*}$ \\
\hline \multicolumn{2}{|c|}{ Parents/caregivers under the influence of psychoactive substances } & 25 & 6.0 & 0 & 0 & $<0.001^{*}$ \\
\hline \multicolumn{2}{|l|}{ Stimulants, drugs } & 106 & 26.2 & 0 & 0 & $<0.001^{*}$ \\
\hline \multicolumn{2}{|l|}{ Skipping classes } & 108 & 26.7 & 0 & 0 & $<0.001^{*}$ \\
\hline \multicolumn{2}{|c|}{ Running away from home } & 100 & 24.8 & 0 & 0 & $<0.001^{*}$ \\
\hline \multicolumn{2}{|l|}{ Problems with peers } & 164 & 40.1 & 0 & 0 & $<0.001^{*}$ \\
\hline \multicolumn{2}{|c|}{ Frequent visits to the police station } & 56 & 13.9 & 0 & 0 & $<0.001^{*}$ \\
\hline \multicolumn{2}{|c|}{ Difficulties in concentration and learning } & 205 & 50.7 & 21 & 5.6 & $<0.001^{*}$ \\
\hline
\end{tabular}

\footnotetext{
* Statistically significant.
} 


\begin{tabular}{|c|c|c|c|c|c|}
\hline \multirow[t]{2}{*}{ Socioeconomic factors } & \multicolumn{5}{|c|}{ Spearman's rank correlation $\left[r_{s}\right]$} \\
\hline & Dysfunctional family & Presence of abuse & Physical abuse & Sexual abuse & Emotional abuse \\
\hline Age of parents & $-0.173^{*}$ & $-0.113^{*}$ & -0.051 & -0.018 & $-0.119 *$ \\
\hline Economic status & $-0.704 *$ & $-0.455^{*}$ & $-0.282^{*}$ & $-0.101^{*}$ & $-0.447 *$ \\
\hline Education & $-0.652^{*}$ & $-0.466 *$ & $-0.287^{*}$ & $-0.075^{*}$ & $-0.647 *$ \\
\hline
\end{tabular}

$* p$-value $<0.001$.

\begin{tabular}{|c|c|c|c|c|}
\hline \multirow[t]{2}{*}{ Correlated behavior } & \multicolumn{4}{|c|}{ Spearmen's rank correlation $\left[r_{S}\right]$} \\
\hline & Dysfunctional family & Presence of abuse & Physical abuse & Emotional abuse \\
\hline Anxiety & $0.457^{*}$ & $0.336^{*}$ & - & $0.331^{*}$ \\
\hline Reduced self-esteem & $0.334 *$ & 0.291* & $0.226 *$ & $0.285^{*}$ \\
\hline Over-confidence & $0.206^{*}$ & - & - & - \\
\hline Reduced mood and motivation & $0.308^{*}$ & $0.268^{*}$ & - & $0.260 *$ \\
\hline Hyper responsibility & $0.231 *$ & - & - & - \\
\hline Aggressive behavior & $0.432^{*}$ & $0.284^{*}$ & - & $0.271 *$ \\
\hline Regressive behavior & $0.217^{*}$ & - & - & - \\
\hline Hyperactivity & $0.231^{*}$ & - & - & - \\
\hline Sense of guilt & $0.362^{*}$ & $0.277^{*}$ & - & $0.217^{*}$ \\
\hline Speech impairments & $0.405^{*}$ & $0.290 *$ & - & $0.298^{*}$ \\
\hline Onychophagia & $0.381^{*}$ & $0.226^{*}$ & - & $0.225^{*}$ \\
\hline Lack of basic hygiene & $0.431 *$ & $0.295^{*}$ & $0.262^{*}$ & $0.302 *$ \\
\hline Mismatched clothing & $0.379 *$ & $0.238^{*}$ & $0.214^{*}$ & $0.244^{*}$ \\
\hline Stimulants, drugs & $0.383^{*}$ & $0.350^{*}$ & - & $0.245^{*}$ \\
\hline Skipping classes & $0.387^{*}$ & $0.255^{*}$ & - & $0.246^{*}$ \\
\hline Running away from home & $0.370^{*}$ & $0.229 *$ & - & $0.235^{*}$ \\
\hline Problems with peers & 0.493* & $0.339 *$ & - & $0.320 *$ \\
\hline Frequent visits to the police station & $0.269 *$ & - & - & - \\
\hline Difficulties in concentration and learning & $0.498^{*}$ & - & $0.205^{*}$ & $0.337 *$ \\
\hline
\end{tabular}

${ }^{*} p$-value $<0.001$.

\begin{tabular}{|c|c|c|c|c|c|c|}
\hline \multirow[t]{2}{*}{ Groups of behaviors } & \multicolumn{2}{|c|}{ Physical abuse } & \multicolumn{2}{|c|}{ Sexual abuse } & \multicolumn{2}{|c|}{ Emotional abuse } \\
\hline & $95 \% \mathrm{Cl}$ & OR & $95 \% \mathrm{Cl}$ & OR & $95 \% \mathrm{Cl}$ & OR \\
\hline Auto-aggressive behavior & $0.34-0.74$ & 0.504 & $0.52-3.67$ & 1.380 & $0.41-0.75$ & 0.553 \\
\hline$p$-value & \multicolumn{2}{|l|}{$p=0.001^{*}$} & \multicolumn{2}{|l|}{$p=0.517$} & \multicolumn{2}{|l|}{$p<0.001^{*}$} \\
\hline Reduced self-esteem & $0.20-0.43$ & 0.291 & $0.18-1.12$ & 0.449 & $0.21-0.39$ & 0.286 \\
\hline$p$-value & \multicolumn{2}{|l|}{$p<0.001^{*}$} & \multicolumn{2}{|l|}{$p=0.086$} & \multicolumn{2}{|l|}{$p<0.001^{*}$} \\
\hline Over-confidence & $0.46-1.02$ & 0.682 & $0.18-1.1$ & 0.456 & $0.35-0.66$ & 0.478 \\
\hline$p$-value & \multicolumn{2}{|l|}{$p=0.063$} & \multicolumn{2}{|l|}{$p=0.092$} & \multicolumn{2}{|l|}{$p<0.001^{*}$} \\
\hline Reduced mood and motivation & $0.23-0.51$ & 0.342 & $0.13-0.94$ & 0.352 & $0.24-0.44$ & 0.325 \\
\hline$p$-value & \multicolumn{2}{|l|}{$p<0.001^{*}$} & \multicolumn{2}{|l|}{$p=0.036^{*}$} & \multicolumn{2}{|l|}{$p<0.001^{*}$} \\
\hline Sense of guilt & $0.29-0.78$ & 0.473 & $0.13-1.08$ & 0.379 & $0.17-0.43$ & 0.272 \\
\hline$p$-value & \multicolumn{2}{|l|}{$p=0.004^{*}$} & \multicolumn{2}{|l|}{$p=0.069$} & \multicolumn{2}{|l|}{$p<0.001^{*}$} \\
\hline Hyper responsibility & $0.43-0.99$ & 0.654 & $0.27-1.94$ & 0.729 & $0.34-0.66$ & 0.475 \\
\hline$p$-value & \multicolumn{2}{|l|}{$p=0.047^{*}$} & \multicolumn{2}{|l|}{$p=0.527$} & \multicolumn{2}{|l|}{$p<0.001^{*}$} \\
\hline Regressive behaviur & $0.46-1.08$ & 0.700 & $0.13-0.83$ & 0.331 & $0.36-0.71$ & 0.508 \\
\hline$p$-value & \multicolumn{2}{|l|}{$p=0.103$} & \multicolumn{2}{|l|}{$p=0.018^{*}$} & \multicolumn{2}{|l|}{$p<0.001^{*}$} \\
\hline Aggressive behavior & $0.30-0.71$ & 0.458 & $0.15-1.02$ & 0.395 & $0.17-0.37$ & 0.252 \\
\hline$p$-value & \multicolumn{2}{|l|}{$p<0.001^{*}$} & \multicolumn{2}{|l|}{$p=0.055$} & \multicolumn{2}{|l|}{$p<0.001^{*}$} \\
\hline Hyperactivity & $0.54-1.22$ & 0.810 & $0.19-1.18$ & 0.474 & $0.37-0.70$ & 0.508 \\
\hline$p$-value & \multicolumn{2}{|l|}{$p=0.313$} & \multicolumn{2}{|l|}{$p=0.109$} & \multicolumn{2}{|l|}{$p<0.001 *$} \\
\hline Anxiety & $0.22-0.49$ & 0.327 & $0.06-0.37$ & 0.143 & $0.13-0.28$ & 0.193 \\
\hline$p$-value & \multicolumn{2}{|l|}{$p<0.001^{*}$} & \multicolumn{2}{|l|}{$p<0.001^{*}$} & \multicolumn{2}{|l|}{$p<0.001^{*}$} \\
\hline
\end{tabular}




\begin{tabular}{|c|c|c|c|c|c|c|}
\hline \multirow[t]{2}{*}{ Groups of behaviors } & \multicolumn{2}{|c|}{ Physical abuse } & \multicolumn{2}{|c|}{ Sexual abuse } & \multicolumn{2}{|c|}{ Emotional abuse } \\
\hline & $95 \% \mathrm{Cl}$ & OR & $95 \% \mathrm{Cl}$ & OR & $95 \% \mathrm{Cl}$ & OR \\
\hline \multicolumn{7}{|l|}{ Others } \\
\hline Difficulties in concentration and learning & $0.22-0.48$ & 0.326 & $0.11-0.72$ & 0.285 & $0.16-0.30$ & 0.217 \\
\hline$p$-value & \multicolumn{2}{|l|}{$p<0.001^{*}$} & \multicolumn{2}{|l|}{$p=0.008^{*}$} & \multicolumn{2}{|l|}{$p<0.001^{*}$} \\
\hline Stimulants, drugs & $0.19-0.48$ & 0.304 & $0.12-0.88$ & 0.327 & $0.16-0.37$ & 0.242 \\
\hline$p$-value & \multicolumn{2}{|l|}{$p<0.001^{*}$} & \multicolumn{2}{|l|}{$p=0.027^{*}$} & \multicolumn{2}{|l|}{$p<0.001^{*}$} \\
\hline Problems with peers & $0.23-0.54$ & 0.354 & $0.07-0.45$ & 0.178 & $0.14-0.29$ & 0.203 \\
\hline$p$-value & \multicolumn{2}{|l|}{$p<0.001^{*}$} & \multicolumn{2}{|l|}{$p<0.001 *$} & \multicolumn{2}{|l|}{$p<0.001 *$} \\
\hline Skipping classes & $0.21-0.53$ & 0.331 & $0.12-0.90$ & 0.334 & $0.16-0.37$ & 0.244 \\
\hline$p$-value & \multicolumn{2}{|l|}{$p<0.001^{*}$} & \multicolumn{2}{|l|}{$p=0.030^{*}$} & \multicolumn{2}{|l|}{$p<0.001^{*}$} \\
\hline Running away from home & $0.24-0.63$ & 0.391 & $0.11-0.82$ & 0.304 & $0.16-0.39$ & 0.249 \\
\hline$p$-value & \multicolumn{2}{|l|}{$p<0.001^{*}$} & \multicolumn{2}{|l|}{$p=0.019^{*}$} & \multicolumn{2}{|l|}{$p<0.001 *$} \\
\hline Frequent visits to the police station & $0.15-0.49$ & 0.272 & $0.18-10.7$ & 1.398 & $0.13-0.40$ & 0.226 \\
\hline$p$-value & \multicolumn{2}{|l|}{$p<0.001^{*}$} & \multicolumn{2}{|l|}{$p=0.746$} & \multicolumn{2}{|l|}{$p<0.001^{*}$} \\
\hline $\begin{array}{l}\text { Mismatched clothing - too big, too small, } \\
\text { inadequate for the season or gender }\end{array}$ & $0.17-0.42$ & 0.263 & $0.11-0.65$ & 0.250 & $0.16-0.37$ & 0.240 \\
\hline$p$-value & \multicolumn{2}{|l|}{$p<0.001^{*}$} & \multicolumn{2}{|l|}{$p=0.004^{*}$} & \multicolumn{2}{|l|}{$p<0.001^{*}$} \\
\hline Lack of basic hygiene, presence of lice & $0.14-0.34$ & 0.219 & $0.13-0.84$ & 0.326 & $0.13-0.29$ & 0.196 \\
\hline$p$-value & \multicolumn{2}{|l|}{$p<0.001^{*}$} & \multicolumn{2}{|l|}{$p=0.021 *$} & \multicolumn{2}{|l|}{$p<0.001 *$} \\
\hline Onychophagia & $0.20-0.50$ & 0.316 & $0.2-0.87$ & 0.323 & $0.28-0.42$ & 0.272 \\
\hline$p$-value & \multicolumn{2}{|l|}{$p<0.001^{*}$} & \multicolumn{2}{|l|}{$p=0.025^{*}$} & \multicolumn{2}{|l|}{$p<0.001^{*}$} \\
\hline Speech impairments & $0.24-0.58$ & 0.377 & $0.07-0.45$ & 0.180 & $0.14-0.31$ & 0.201 \\
\hline$p$-value & \multicolumn{2}{|l|}{$p<0.001^{*}$} & \multicolumn{2}{|l|}{$p<0.001^{*}$} & $p<0.001^{*}$ & \\
\hline
\end{tabular}

* Statistically significant.

Among the disturbing factors, the economic status of the family seems to have the greatest influence. Spearman's rank correlation shows a weak and moderate correlation between a dysfunctional family, presence of abuse, physical and emotional abuse and observed behaviors (Table 4).

Logic regression analysis was performed to show the connections between observed behaviors and type of violence experienced. The presence of emotional violence increases the probability of the occurrence of all observed behaviors. Similar results were observed for the presence of physical violence (except for regressive behaviors, hyperactivity and over-confidence). The presence of sexual abuse increases the probability of the occurrence of reduced mood and motivation, regressive behaviors and excessive anxiety (Table 5).

\section{Discussion}

Due to low social awareness and the complexity of the phenomenon of domestic violence (relationship of dependence, shame and fear), the problem of child abuse and neglect remains largely undisclosed [11, 12]. Children growing up in a family where conflicts, improper behavior, impending aggression and, very frequent, violence, negligence and abuse occur constantly see such a model of a family as typical [13]. Symptoms of child abuse can be noticed by a dentist during examination, treatment or during an interview. During examination, we may observe symptoms of dental neglect, such as severe caries, tooth wear, signs in oral mucosa, as well as higher rate of tooth injures or parafunctional habits. In the dental office, from the psychological point of view, children, through contact with a stressful situation, may expose a specific behavior. Professionals may observe the communication which occurs during a dental visit between their patient and parents, as well as patient and doctor and medical staff [14]. A meta-analysis carried out by Gershoff and Grogan-Kaylor [15] identified negative consequences of experiencing violence in childhood, such as: aggression, antisocial behavior, low moral internalization, mental health problems, parent-child relationship disorders, cognitive impairment or low self-esteem. According to our study, children and adolescents as victims of domestic violence present different kinds of behavioral disorders during dental treatment: reduced self-esteem, a sense of helplessness, indifference, reduced mood and depression. They tend to be psychomotor hyperactive, over-confident and overly responsible. In different ways, they can react to stressful situations, presenting regressive behavior, being aggressive or anxious and being withdrawn. Milton Erikson assumes that in the development of a child, there are periods of crisis, the constructive passage of which contributes to the constitution of a stable, mature personality. According to this identity development model, from the moment of birth, man goes through successive stages of development (related to age), which require the development of new forms of adaptation to the surrounding environment and the realization of its needs. Erikson has distinguished several periods of conflict with which a child has to confront during his development. Improper passage through these periods influences the development of communication and adaptation to problems, which can be observed in a child's behavior (problems with trust and security, sense of guilt, fear, aggression) [16]. Eriksson's identity development model fits to the observations and conclusions which a conducted study of children coming from dysfunctional families reviled. The proper process of growing up and the development of social and emotional skills in the case of children from the study group may be disturbed by the family and social situation. Magurie-Jack et al. [17] found that abuse at age 1-3 was associated with a higher level of externalizing behavior at age 3 and a higher level of internalizing and externalizing behavior at age 5 . The authors did not find an association between child abuse and cognitive skills.

Our study found a strong correlation between economic status, education level and the presence of physical and emotional abuse. Families living in disadvantaged circumstances may experience greater levels of stress, isolation and family conflict. 
Socioeconomic factors like poverty, lack of education, mental and alcohol-related illnesses are a cause of the failure to ensure an appropriate environment for the development of the child in the health, educational and emotional-national spheres. Other risk factors for child abuse and neglect found in literature are: unemployment, large number of children in the family, divorce and separation [18-20]. A visible manifestation of neglect is insufficient weight and low height of the child in relation to the norm, dirty underwear and sloppy clothing, often not adapted to the season of the year or gender, unattended injuries, as well as the child's tiredness and apathy [21-23]. These observation are in line with the results of our study, in which we observe among children from dysfunctional families: mismatched clothing - too big, too small, inadequate for the season or gender $(25.7 \%$ vs $0 \%)$, lack of basic hygiene ( $31.9 \%$ vs $0 \%)$, abnormal body weight ( $31.4 \%$ vs $2.9 \%$ ), apathy $(29.2 \%$ vs $2.6 \%)$. Substance misuse is one of the most commonly investigated risk factors in literature on child maltreatment [23-27]. Researchers observed that children of alcoholics exhibit higher rates of antisocial behavior than control subjects [25]. In the presented study, the antisocial behavior of patients from the study group was statistically more frequently observed when compared with controls. The child's relationship at school and within their family produces impacts on self-esteem construction [28]. In our study, communicational problems with peers was observed in $39.9 \%$ $(n=161)$ of children from the study group $(39.9 \%$ vs $0 \%, p<$ 0.001 ). $26.7 \%$ of them did not regularly attend school and frequently ran away from home $(24.8 \%$ vs $0 \%, p<0.001)$. According to a police report in Poland, in $65 \%$ of cases of domestic violence, the perpetrator was under the influence of alcohol [29]. The interesting research was presented by Sudeshni [30], who examined that $35 \%$ (300 cases reviewed) of perpetrators were under the influence of alcohol or drugs when they committed the offence. In our study, substance misuse concerned $67.58 \%$ of parents and $26.2 \%$ of children from the study group.

Maltreating parents have been found to be deficient with communication, interactions with the child, stress and anger control [31]. Indicators for problems in parent-child interactions may include: low level of every-day iterations, lack of interest in dental treatment and the state of oral health and hygiene, high levels of hostile interaction (yelling, shouting, pejorative language), infrequent demonstrations of verbal or physical encouragement (praise, hugging, holding a hand) [14, 32]. Children from families in which problems with interpersonal relationships are observed are more aggressive and more often show symptoms of depression [33]. During the study, an aggressive interaction between children and caregivers was observed, as well as using pejorative language and physical force to motivate the child to dental treatment. Leaving the child alone in the stressful situation of dental treatment leads to uncertainties and anxious behavior, and on the other hand, children may become more aggressive, ignoring the doctor and behaving in an impertinent way, which was presented in the results of this study. Compared to controls, parents of neglected children present a more restrictive attitude, providing less loving care and attention. "Parentification" (terminology described by Schier et al.) is the process whereby a child sacrifices his own needs (needs related to action, emotional needs) in order to fulfill parental expectations and needs [33]. In the presented study, we confirmed that children at risk of experiencing or witnessing violence present an overly responsible attitude ( $18 \%$ vs $2 \%$, $p<0.001)$, taking care of themselves, siblings and even parents.

The family environment in which the child lives is a reference point for one's further development. Through imitation, children learn models of communication, stress magnitude strategies and problem-solving strategies. The development of these models depends on the personal condition of the child, the age at which the trauma occurred and the surrounding environment. Children under the age of six spend extended periods of time alone with a parent, are completely dependent on the parents for their basic needs and are more vulnerable to physical injury than older children $[1,34]$. A child transfers these learned models of behaviors onto the stressful situation in the dentist office and to the relationship with the doctor [32, 35-37]. Difficulties in communication and less cooperativeness during the performance of dental procedures were also observed in the study, i.e. ignoring the doctor, not answering the questions, using insulting or obscene language, pejorative language, excessive physical contact, shortening of distance, good cooperation after boundary setting on the other hand displaying apathy and confused attitude. This finding is in line with a previous study on the association of child abuse and neglect and behavior management problems in pediatric dentistry, e.g. stoicism during dental procedures, quiet and passive acceptance of even painful treatment [38, 39]. In addition to behavioral disorders in the dental office, we can also observe physical signs of extreme tension, such as urinary incontinence $(4.7 \%$ vs $0 \%, p<0.001)$, selfmutilation $(4.2 \%$ vs $0 \%, p<0.001)$, nail biting $(26 \%$ vs $0 \%$, $p<0.001)$, lack of basic hygiene $(31.9 \%$ vs $0 \%, p<0.001)$, nervous play with hands ( $14.6 \%$ vs $0.0 \%, p<0.001)$, speech fluency disorders $(20.63 \%$ vs $1.6 \%, p<0.001)$, eating disorders ( $30 \%$ vs $7 \%, p<000.1$ ). Similar to our observation, Harris et al. [14] in their studies noticed self-harm, lip, cheek or nail biting, prolonged finger sucking. The etiology of speech and eating disorders is attributed to anxiety or a severe stressful situation. In $90 \%$ of cases, speech fluidity disorders occur in the pre-school period [40]. Lack of fluency in speech can be perpetuated by various social reactions, e.g. criticism, fighting between parents, violence against a child or the excessive demands of parents $[40,41]$. Eating disorders are also considered in literature as one of the predictors of child abuse and neglect and are associated with neglect, sexual assault, sexual harassment, physical abuse and assault, emotional abuse, as well as emotional and physical neglect $[42,43]$. Traumatic experience can cause disruption in the nervous system, which may make it difficult for individuals to manage their emotions, to manage a stressful situation and may cause specific behaviors, problems with communication, psychosomatic manifestation, e.g. speech disorders, turning to compulsive reactions, e.g. eating disorders, other addictions or developing parafunctional habits. These developed defenses mechanism can be a way to ease emotional stress and should be observed and detected by a professional in order to counteract child abuse and neglect.

\section{Conclusions}

Increasing awareness of the symptoms of child abuse among dentists and the entire dental team (nurses, dental assistance, receptionists) is an important aspect in preventing child abuse. Children and adolescents being victims of domestic violence present different kinds of behavioral disorders: reduced self-esteem, a sense helplessness, indifference, reduced mood and depression. They tend to be psychomotor hyperactive, over-confident and overly responsible. In different ways, they can react to stressful situations, presenting regressive behavior, being aggressive or anxious and being withdrawn. Behavioral observation and detailed social interviews are additional and indispensable tools for assessing the incidence of domestic violence in the dental office. Low economic status and education level are important risks factors for child abuse and neglect. All members of the dental team share a responsibility to safeguard children from abuse and neglect. Thanks to empathic observation, we are able to notice behavioral disorders during a dental appointment and react early enough through conversation with parents/caregivers, suggesting help or referral to appropriate social welfare centers and/or police in the case of direct danger to life or suspicion of a crime.

Source of funding: This work was funded from the authors' own resources.

Conflicts of interest: The authors declare no conflicts of interest. 


\section{References}

1. Behind closed door: the impact of domestic violence on children. United Nations Children's Fund (UNICEF), United States of America; 2006.

2. World Health Organization. Preventing child maltreatment: a guide to taking action and generating evidence 2006 [cited 7.10.2007]. Available from URL: http://whqlibdoc.who.int/publications/2006/9241594365eng.pdf.

3. Wekerle $C$, Leung $E$, Wall $A$, et al. The contribution of childhood emotional abuse to teen dating violence among child protective services-involved youth. Child Abuse Neglect 2009; 33(1): 45-58.

4. Ptaszyńska-Sarosiek I, Niemcunowicz-Janica A, Iłędo M, et al. Zespół dziecka krzywdzonego w materiale Zakładu Medycyny Sądowej Uniwersytetu Medycznego w Białymstoku. Arch Med Sqd 2017; 67(3): 153-165 (in Polish).

5. Welbury R. Dental neglect, child maltreatment, and the role of dental profession. Contemp Clin Dent 2016; 7(3): 285-286.

6. Needleman HL. Orofacial trauma in child abuse: types, prevalence, management, and the denta Iprofession's involvement. Pediatr Dent 1986; 8: 71-80.

7. Jessee SA. Physical manifestations of child abuse to the head, face, and mouth. J Dent Child 1995; 62: 245-249.

8. Thomas JE, Straffon L, Inglehart MR. Knowledge and professional experiences concerning child abuse: an analysis of provider and student responses. Pediatr Dent 2006; 28: 438-444.

9. Kellogg N. Oral and dental aspects of child abuse and neglect. Pediatr 2005; 116: 1565-1568.

10. Adams JA. Medical evaluation of suspected child sexual abuse: 2011 update journal of child sexual abuse. J Child Sex Abuse 2011; 20(5): 588-605.

11. Kagan R, Schlosberg S. Families in perpetual crisis. New York: W. W. Norton \& Company; 1989.

12. Horst-Sikorska W, Bryl N. Zespół Dziecka Maltretowanego. Fam Med Prim Care Rev 2011; 13(2): 319-321 (in Polish).

13. Masteller J, Stoop D. Forgiving our parents, forgiving ourselves: healing adult children of dysfunctional families. Vine Books; 2011.

14. Harris J, Sidebotham P, Welbury R, et al. Child protection and the dental team: an introduction to safeguarding children in dental practice. Committee of Postgraduate Dental Deans and Directors; 2010.

15. Gershoff ET, Grogan-Kaylor A. Spanking and child outcomes: old controversies and new meta-analyses. J Fam Psychol 2016; 30(4): 453.

16. Erikson EH. Tożsamość a cykl życia. Poznań: Zysk i S-ka; 2004.

17. Maguire-Jack K, Gromoske AN, Berger LM. Spanking and child development during the first 5 years of life. Child Dev 2012; 83(6): 1960-1977.

18. Wójcik S. Przemoc w rodzinie, zaniedbanie, wiktymizacja pośrednia. Wyniki ogólnopolskiej diagnozy problemu przemocy wobec dzieci. Dziecko krzywdzone. Teoria Badania Praktyka 2013; 12(3): 40-62 (in Polish).

19. Jarosz E, Nowak A. Dzieci ofiary przemocy w rodzinie. Raport Rzecznika Praw Dziecka. Funkcjonowanie znowelizowanej Ustawy o przeciwdziałaniu przemocy w rodzinie. Warszawa: Biuro Rzecznika Praw Dziecka; 2012 (in Polish).

20. Faus DP, de Moraes $\mathrm{CL}$, Reichenheim ME, et al. Childhood abuse and community violence: risk factors for youth violence. Child Abuse Neg/ 2019; 98: 104-182.

21. Benbenishty R, Davidson-Arad B, López M, et al. Decision making in child protection: an international comparative study on maltreatment substantiation, risk assessment and interventions recommendations, and the role of professionals' child welfare attitudes. Child Abuse Neg/ 2015; 49: 63-75.

22. Hibbard R, Barlow J, MacMillan H, et al. Committee on Child Abuse and Neglect. Psychological maltreatment. Pediatr 2012; 130(2): 372-378.

23. Vidal S, Prince D, Connell CM, et al. Maltreatment, family environment, and social risk factors: determinants of the child welfare to juvenile justice transition among maltreated children and adolescents. Child Abuse Neg/ 2017; 63: 7-18.

24. Holland S, Forrester D, Williams A, et al. Parenting and substance misuse: understanding accounts and realities in child protection contexts. B J Soc Work 2014; 44(6): 1491-1507.

25. Velleman R, Templeton LJ. Impact of parents' substance misuse on children: an update. B J Psych Advances 2016; 22(2): $108-117$.

26. Victor BG, Grogan-Kaylor A, Ryan JP, et al. Domestic violence, parental substance misuse and the decision to substantiate child maltreatment. Child Abuse Neg/ 2018; 79: 31-41.

27. Laslett AM, Room R, Dietze P, et al. Alcohol's involvement in recurrent child abuse and neglect cases. Addiction 2012; 107(10): 1786$-1793$.

28. Lourenço CB, Lima Saintrain MV de, Vieira APGF. Child, neglect and oral health. BMC Pediatr 2013; 13(1): 188.

29. Komenda Główna Policji. Wybrane statystyki. Przemoc w rodzinie [cited 20.02.2019]. Available from URL: http://www.policja.pl (in Polish).

30. Sudeshni N. Profile of the oro-facial injuries in child physical abuse at a Children's Hospital. Child Abuse Neg/ 2000; 24: 521-534.

31. Camilo C, Garrido MV, Calheiros MM. Implicit measures of child abuse and neglect: a systematic review. Aggress Violent Behav 2016; 29: 43-54.

32. Kvist T, Annerbäck EM, Dahllöf G. Oral health in children investigated by social services on suspicion of child abuse and neglect. Child Abuse Neg/ 2018; 76: 515-523.

33. Schier K. Dorosłe dzieci - psychologiczna problematyka odwrócenia ról w rodzinie. Warszawa: Wydawnictwo Naukowe Scholar; 2015 (in Polish).

34. Harwas-Napierała B, Trempała J. Psychologia rozwoju człowieka. Charakterystyka okresów życia człowieka. Warszawa: Wydawnictwo Naukowe PWN; 2011 (in Polish).

35. Kim K, Mennen FE, Trickett PK. Patterns and correlates of co-occurrence among multiple types of child maltreatment. Child Fam Soc Work 2017; 22(1): 492-502.

36. Vidal S, Prince D, Connell CM, et al. Maltreatment, family environment, and social risk factors: determinants of the child welfare to juvenile justice transition among maltreated children and adolescents. Child Abuse Negl 2017; 63: 7-18.

37. Montecchi PP, DiTrani M, SarziAmade D, et al. The dentist's role in recognizing childhood abuses: study on the dental health of children victims of abuse and witnesses to violence. Eur J Paediatr Dent 2009; 10: 185-187.

38. Vodanović M. Child abuse and neglect-considerations for the dental practitioner. Bilten Stomatologia BIH 2007; 9(27-28): 7-13.

39. Gustafsson A, Arnrup K, Broberg AG, et al. Psychosocial concomitants to dental fear and behaviour management problems. Int J Paediatr Dent 2007; 17(6): 449-459.

40. Tarkowski Z, Hemenluk E. Jąkanie jako zaburzenie psychosomatyczne. Sztuka Leczenia 2016; 2: 21-29 (in Polish).

41. Johar N, Sunil MK, Malik U, et al. Acknowledgement and awareness of child abuse and neglect in dentist perspective. Int J Drug Res Dent Sci 2020; 2(3): 1-5. 
42. Mitchell KD, Mazzeo SE, Schlesinger MR, et al. Comorbidity of partial and subthreshold PTSD among men and women with eating disorders in the National Comorbidity Survey-Replication Study. Int J Eat Disorder 2012; 45(3): 307-315.

43. Dunkley DM, Masheb RM, Grilo CM. Childhood maltreatment, depressive symptoms, and body dissatisfaction in patients with binge eating disorder: the mediating role of self-criticism. Int J Eat Disorder 2010; 43(3): 274-281.

Tables: 5

Figures: 0

References: 43

Received: 22.06 .2020

Reviewed: 10.08 .2020

Accepted: 11.10 .2020

Address for correspondence:

Anna Pantelewicz, MD

Zakład Stomatologii Dziecięcej

Uniwersyteckie Centrum Stomatologii

Warszawski Uniwersytet Medyczny

ul. Binieckiego 6

02-097 Warszawa

Polska

Tel.: +48 22 11-66-424

E-mail: annapantelewicz@gmail.com 